\title{
Platform-basin transitions and their role in Alpine-style collision systems: a comparative approach
}

\author{
Cameron Bell ${ }^{1} \cdot$ Robert W. H. Butler $^{1}{ }_{(\mathbb{C}}$
}

Received: 6 June 2016/ Accepted: 9 December 2016/Published online: 10 January 2017

(c) The Author(s) 2017. This article is published with open access at Springerlink.com

\begin{abstract}
The structure of Alpine-type orogenic belts is widely assumed to have been strongly influenced by the inherited structure of the rifted continental margins from which they were formed. The challenge lies in deciphering these influences when orogenic contraction is strong. Contractional deformation in the Kamchia basin (SW Black Sea), caught between the Balkan orogenic belt and the stable Moesian block, has been arrested, preserving the early development of an Alpine-type orogen. We use 3D seismic and well-data to examine the tectonic and stratigraphic structure of this basin. Significant deformation has occurred underwater, through inversion tectonics within the basin itself. However, the basin margin structures have not reactivated. This margin is marked by a low-angle unconformity across which sediment was routed from the platform into the fledgling syn-orogenic basins. Such pathways may explain non-orogen-derived sediment within parts of the ancestral Apennine foredeep, for example. The role of platform margins to focus contractional deformation may have been over-emphasised elsewhere in the Alpine system. Further, the more strongly subsided portions of rifted margins may have accommodated significant contractional deformation through reactivation of basin faults. In the western Alps the complexity of structural juxapositions across thrust sheets in the Brianconnais may reflect these early-orogenic deformations rather than be the product of deformation that happened after tectonic burial.
\end{abstract}

Editorial handling: C. Sue and S. Schmid.

Robert W. H. Butler

rob.butler@abdn.ac.uk

1 Geology and Petroleum Geology, School of Geosciences, University of Aberdeen, Aberdeen AB24 3UE, UK
These early deformations are likely to be recorded in early syn-tectonic depositional sequences.

Keywords Orogenic front - Balkanides · Western Alps · Moesian platform $\cdot$ Kamchia basin

\section{Introduction}

The role of inherited structures in the development of orogenic belts has long been recognized. However, combinations of erosion, deep burial, deformation and tectonic rejuxtapositions make the interpretation of pre-orogenic basin systems in mountain belts problematic and nonunique. The approach adopted here is to use the only weakly developed Balkan orogeny on SW margin of the Black Sea to inform understanding of Alpine-type orogenic systems and the role of precursor basin systems. We use existing interpretations together with 3D seismic data, tied to wells, to develop structural-stratigraphic understanding of a large-scale platform-basin transition within the former Tethyan realm and its partial incorporation into the Tertiary Balkan orogen. This case study then informs discussion of tectonostratigraphic models for part of the western Alps.

Many of the ideas and concepts of geological inheritance in orogenic belts have come from the Alps. The tradition of relating contractional deformation to the architecture of pre-existing sedimentary basins reaches back at least as far as Argand's (1916) depiction of embryo-tectonics (reprised and introduced to an Englishspeaking audience by Collet 1927). Models that invoke reactivation of the normal fault systems that accommodated the pre-orogenic sedimentary basins (e.g. Jackson 1980) are now generally viewed as being too simplistic (see Butler et al. 2006 for review). Recent work in the 
external western Alps (e.g. Dumont et al. 2008; Bellahsen et al. 2012) demonstrates the interaction between inherited faults and distributed deformation within the basement. On the scale of the entire orogen, Mohn et al. (2014) postulate that it is the first-order structure of the rifted continental margin and its components in the context of hyperextension that exert the fundamental control on the architecture of the Alpine orogeny. In this regard they propose that the transition between weakly rifted continent-ward crust and the substantially greater-thinned parts of the margin acts as a fundamental buttress, concentrating crustal shortening. This is the so-called "necking zone" of Mohn et al. (2012). In the western Alps a "necking zone" has been postulated to lie between what is now the tectonically thickened external crystalline basement massifs (e.g. the Ecrins) and the deformed Mesozoic sedimentary successions of the Brianconnais/Subbrianconnais domains (Mohn et al. 2014; Fig. 1a). These two domains are now juxtaposed by the Frontal Pennine Thrust. As Butler (1989) points out, simple juxtaposition is insufficient to demonstrate reactivation. That the Pennine Front coincides with any specific component of the ancestral rifted margin relies on the geological interpretation of deep crustal reflection profiles (e.g. the ECORS-CROP profile, as interpreted by Mohn et al. 2014) and other seismological soundings (e.g. Zhao et al. 2015). Compared with the application of such methods to sedimentary basins, the interpretation of these data is at best ambiguous. Consequently we now turn our attention to a possible geological analogue for the palaeotectonic setting envisaged by Mohn et al. $(2012,2014)$ and others.

\section{Tectonic setting of the Kamchia basin}

The Balkan orogen is part of the greater Alpine system (Fig. 2a) that formed by closure of the Tethyan ocean basins and the subsequent shortening of its former rifted continental margins (e.g. Stampfli and Hochard 2009). The orogen trends E-W and runs for over $400 \mathrm{~km}$ through Bulgaria before plunging eastwards into the SW Black Sea (e.g. Sinclair et al. 1997 and references therein). The Moesian platform forms the outer portion of the Balkan orogen. By the late Cretaceous the SE margin of the Moesian platform represented an abrupt transition into highly stretched continental crust, leading to the oceanic lithosphere of the SW Black Sea (e.g. Nikishin et al. (2015).

A re-entrant of the strongly rifted margin extended westwards from the main Black Sea basin (e.g. Stampfli and Hochard 2009). Much of this was consumed by the formation of main Balkan orogenic belt onshore. The vestigial portion of this re-entrant forms the Kamchia basin (Fig. 2b) and it is this region that provides our case study.

Georgiev (2012) provides a suite of regional "geoseismic" cross-sections through the Kamchia basin and the margin of the Moesian platform, based on vintage 2D seismic profiles and wells. One of these (Fig. 3) serves to introduce the key structural elements as discussed below. Georgiev presents his version with substantial vertical exaggeration. A more realistic display is adopted here (Fig. 3) that has vertical and horizontal scales equal for a uniform seismic velocity of $4 \mathrm{~km} \mathrm{~s}^{-1}$.
Fig. 1 Models for structure and evolution in the Western Alps. a, b illustrate the notion that the lateral variation in crustal structure inherited from the Mesozoic rift history, exerted a fundamental control on orogenic evolution, with a "necking zone" forming a buttress and preferred site of tectonic reactivation during orogeneisis (after Mohn et al. 2014). c, d illustrate the notion that Brianconnais stratigraphic units were taken into the Alpine subduction channel with little disruption so that thrusting and "nappe-stacking" only happened once these units were deeply buried (modified after Michard et al. 2004)
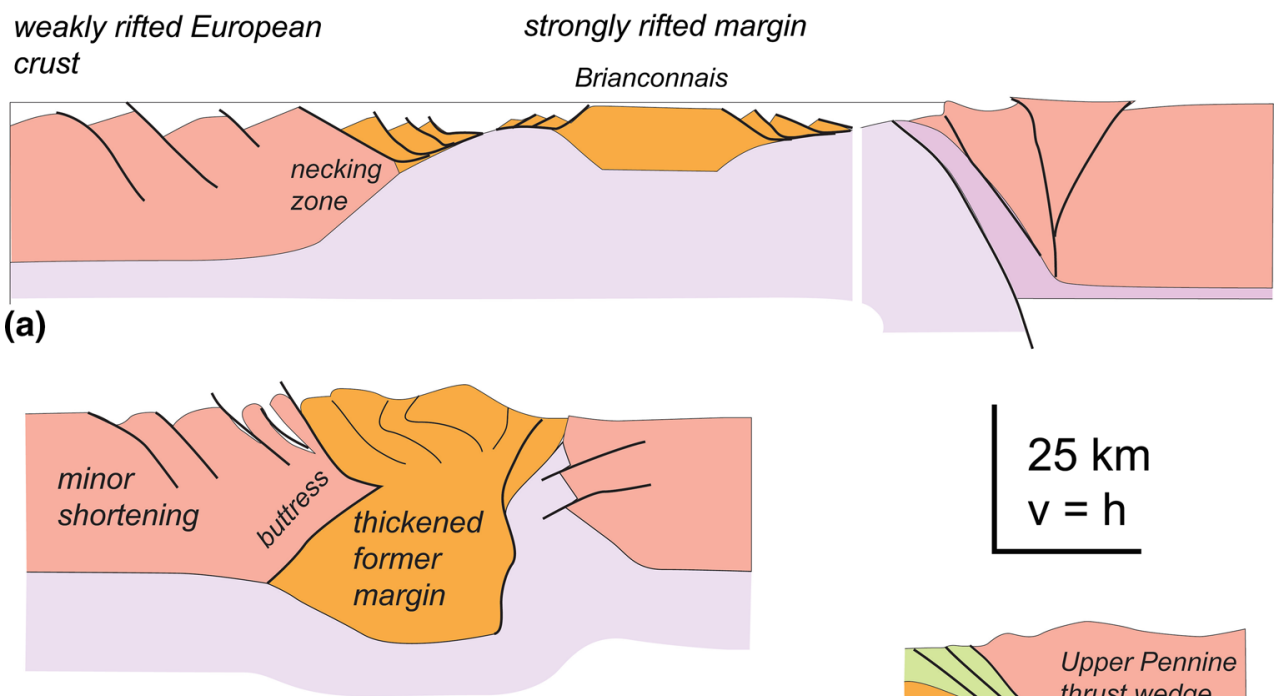

(b)

\section{Restored Brianconnais thrust sheets}

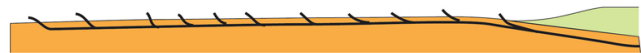

(c)

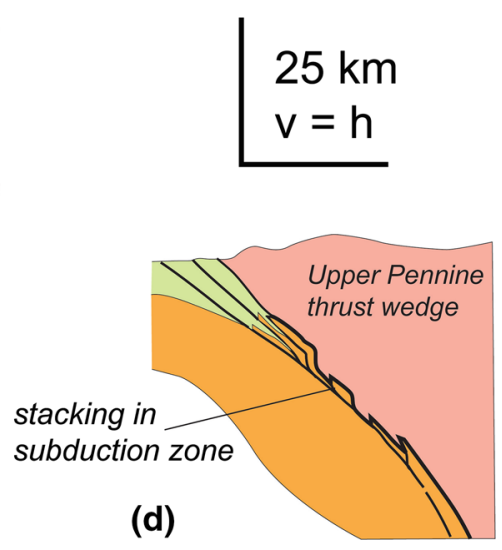


Fig. 2 a Regional map of Alpine chains (shaded) showing selected platform (weakly rifted) regions. The boxed area is that shown in b. b sketch map of the eastern Balkanides and western Black Sea area. The boxed area is the study area (Fig. 4)

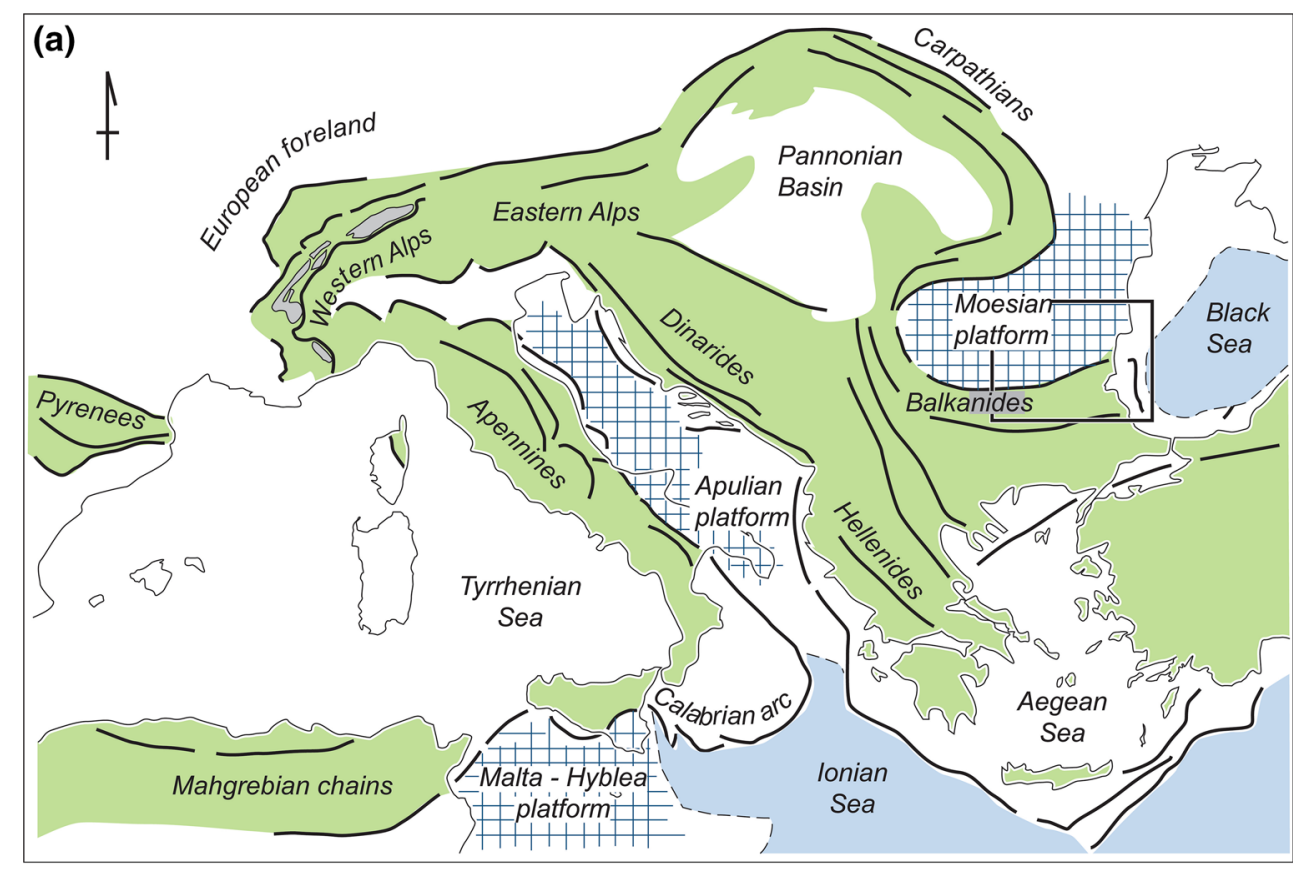

(b)

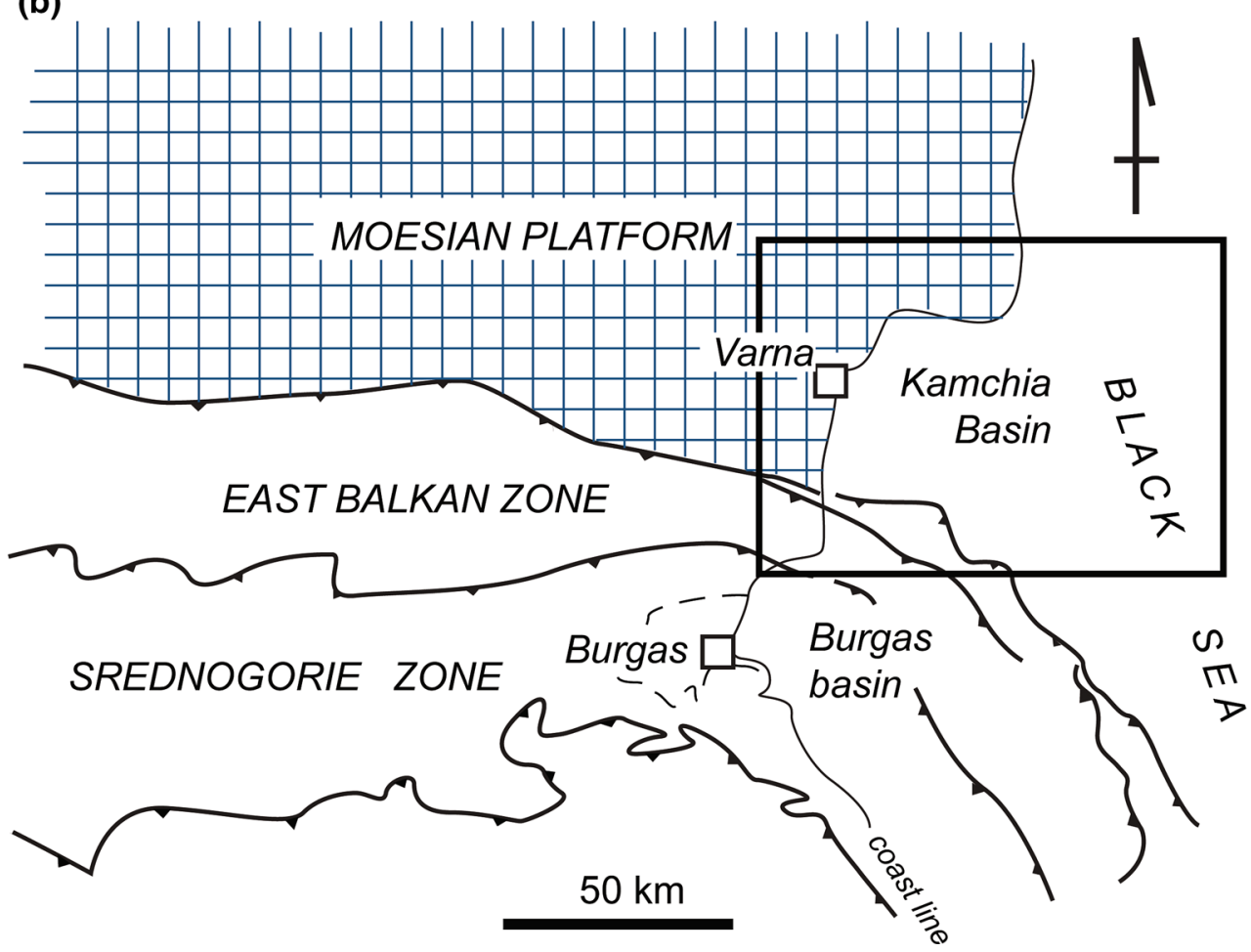

The Moesian platform forms the foreland to the Balkan orogen. It has a reduced Mesozoic-Tertiary succession that is weakly faulted. The southern margin of the platform is defined by the Bliznac Fault. This extensional structure separates the platform from the Kamchia basin. Georgiev's (2012) interpretation shows a dramatic thickening of Tertiary strata across the Bliznac fault into the basin. Stratigraphic thicknesses here exceed $4 \mathrm{~s}$ TWT-equating to around $6-8 \mathrm{~km}$ within the Kamchia basin. These strata overlie Cretaceous and inferred Jurassic successions that, compared with their equivalents on the Moesian platform, are also expanded. The southern part of the basin has become incorporated in thrust systems of the frontal part of the Balkanides.

Cretaceous and Tertiary stata within the Kamchia basin are interpreted as post-rift, thus they are not disrupted by 


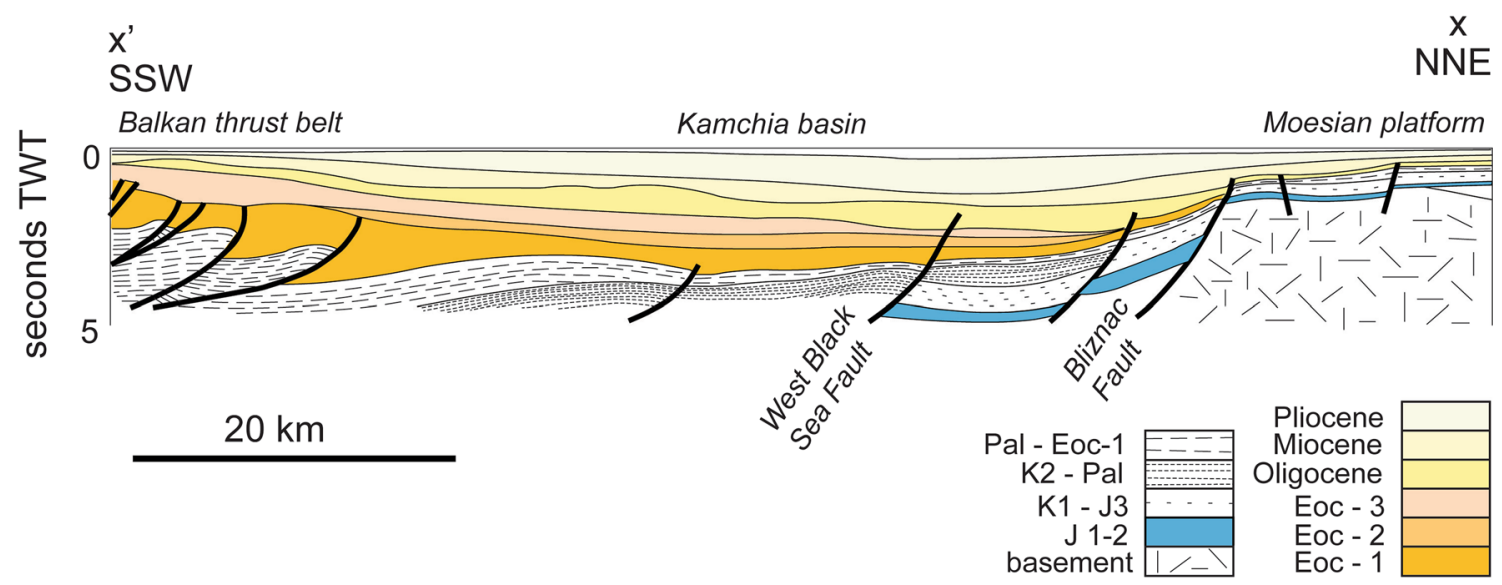

Fig. 3 Cross-section through the Kamchia basin and southern margin of the Moesian platform, based on the geoseismic interpretation of Georgiev (2012) but with vertical and horizontal scales near equal. Location shown on Fig. 4

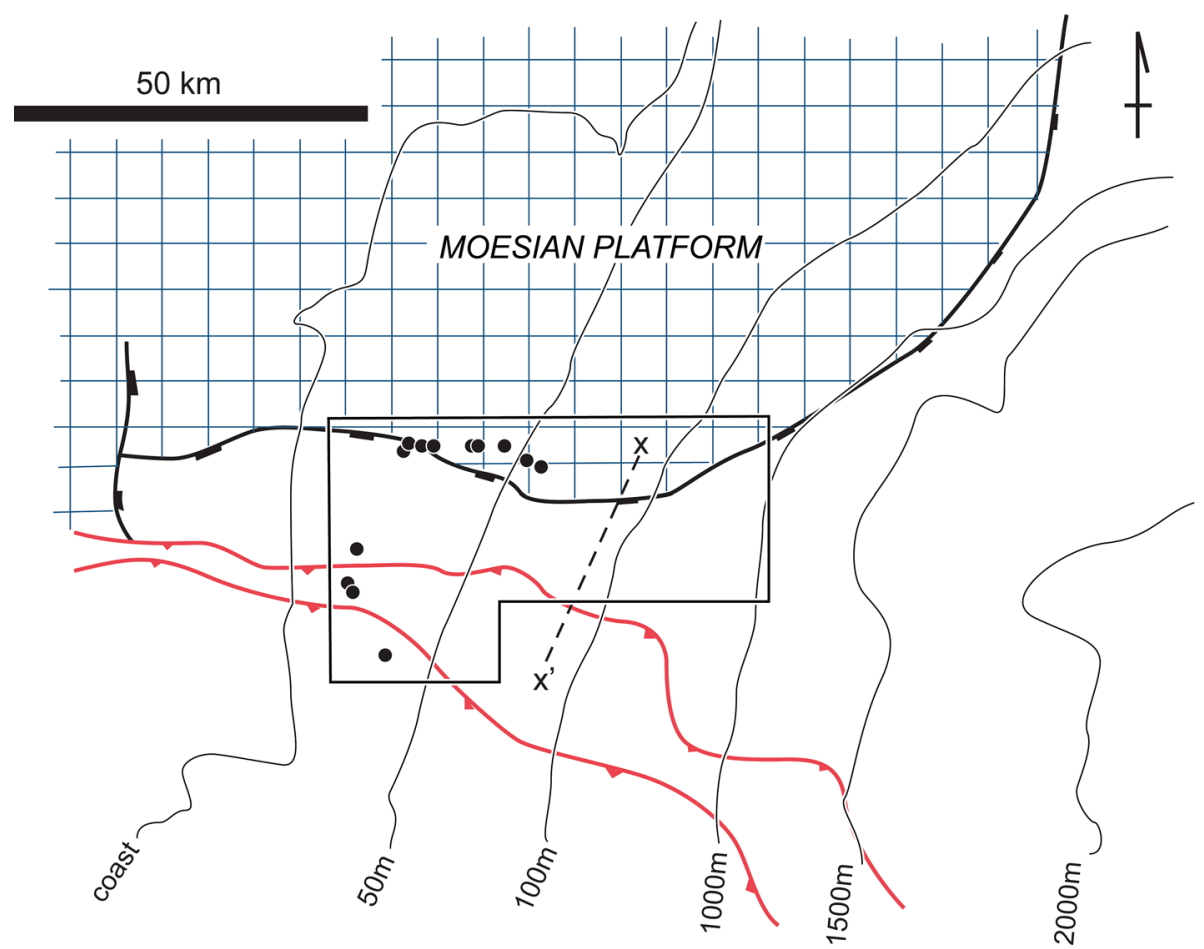

Fig. 4 Map of Kamchia basin with the location of the 3D seismic volume together with wells that underpin this study. Location shown on Fig. 2 b. $x-x^{\prime}$ is the line of section of Fig. 3

the normal faults that formed the basin. However, the early Eocene (Eoc-1) unit on Fig. 3 shows differential thicknesses across the Balkanide thrusts. In contrast, younger strata blanket the thrust system and fill the Kamchia basin. Thus, using Georgiev's (2012) interpretation, significant contractional deformation began and ended in the early Eocene.

Normal faults (e.g. West Black Sea Fault) in the floor of the Kamchia basin show evidence of weak inversion (Fig. 3). This contractional deformation would have been broadly contemporaneous with the Balkan thrust systems. However, the main basin-bounding Bliznac fault has no indications of inversion, with all stratigraphic levels affected by faulting showing normal offsets. Likewise, the normal faults on the Moesian platform have not reactivated under contraction.

\section{Seismic structure}

Georgiev's (2012) interpretations rely on heritage 2D seismic data and give little information on stratal geometries within the main units as illustrated in Fig. 3. Here we 
Fig. 5 Seismic section cut from the 3D seismic volume approximately along the line of Fig. 3. a uninterpreted section shown in TWT. b interpretation of section a. $\mathbf{c}$ the same profile shown with little vertical exaggeration
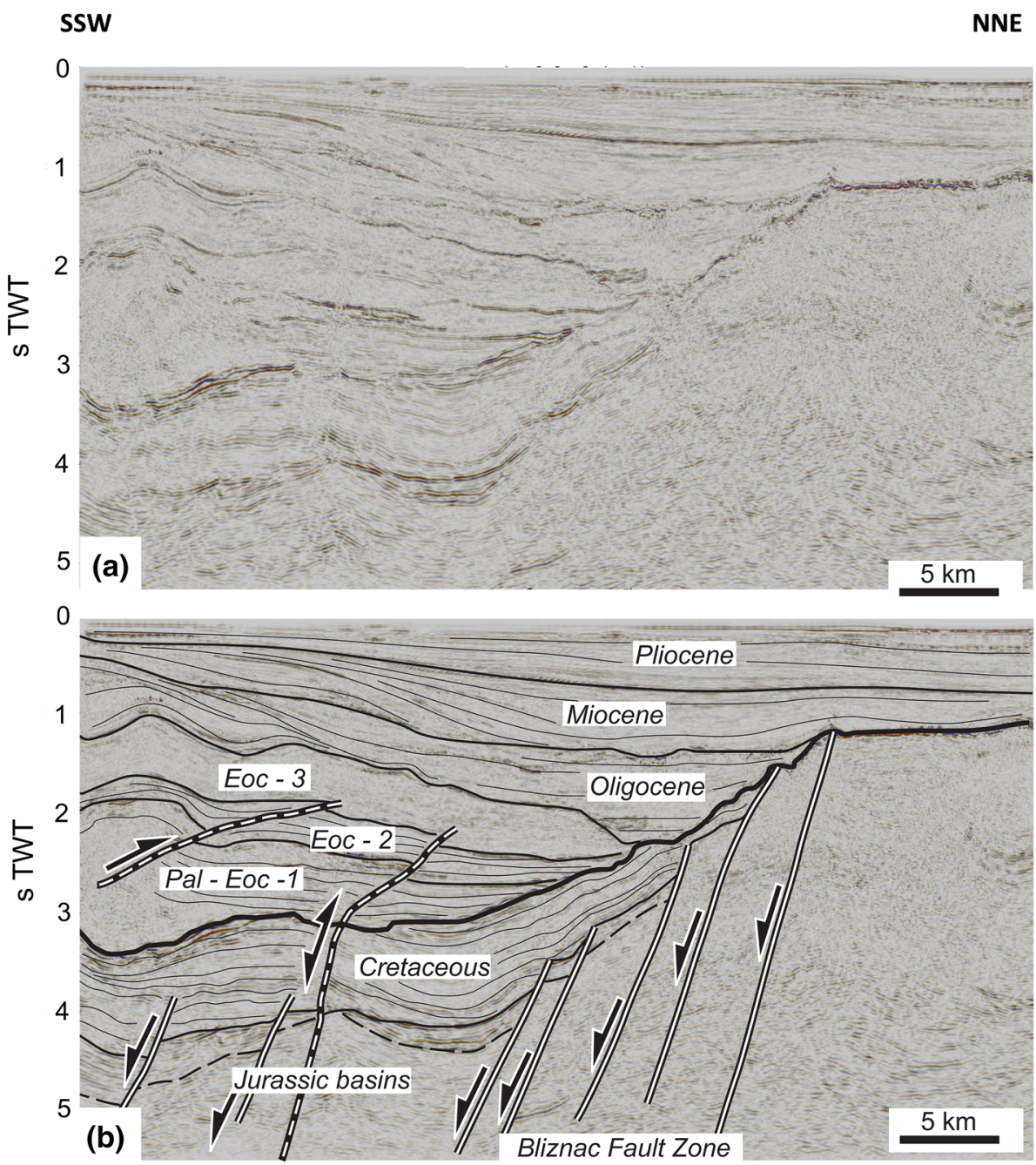

Balkan thrust front

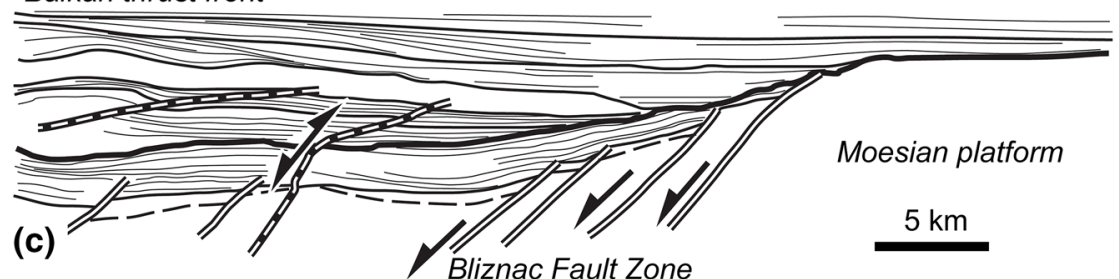

use a 3D seismic dataset covering an area of $1463 \mathrm{~km}^{2}$, acquired in 2004 by the seismic company PGS. Streamer length was $4500 \mathrm{~m}$ with a source separation of $50 \mathrm{~m}$. Within the data footprint 16 exploration wells were used to calibrate the seismic data (Fig. 4). The data have been processed through pre-stack time migration and are displayed here in two-way-time. Interpretations were built using Schlumberger's Petrel software.

The seismic data do not penetrate to great depth (only top $5 \mathrm{~s}$ are useful here) and so the structural underpinnings to the Kamchia Basin are largely unresolved. However, the stratigraphic relationships are well imaged. The seismic stratigraphy of the Kamchia Basin and the adjacent
Moesian platform is illustrated on an interpreted profile extracted from the 3D seismic volume (Fig. 5). Comparison between the clean (Fig. 5a) and annotated (Fig. 5b) allows the reader to judge uncertainties in the interpretations offered here. The section is broadly equivalent to that shown in Fig. 3 but provides greater understanding of tectonostratigraphic relationships.

Reflectors on the Moesian platform, though offset locally, are broadly parallel. We infer these reflectors to represent the parallel-bedded platform carbonates, locally cut by small faults. These strata represent the northern edge of the Kamchia basin. The southern edge of the basin is defined by complex, strongly disturbed reflectors. We 
follow Georgiev's (2012) interpretation that these reflectors represent strata that mark the buried and frontal portion of the Balkan thrust zone. Ahead of this deformed zone, the sedimentary fill of the Kamchia Basin is configured as divergent reflectors that define wedges that taper northwards against the flank of the Moesian platform (Fig. 5). Stratal reflectors converge and apparently onlap this margin. They define an overburden to an unconformity. Well penetrations, described by Georgiev (2012), indicate that the oldest strata above the unconformity are Palaeocene in age-thus we term this surface the sub-Tertiary unconformity. The overlying set of seismic sequences can be identified (Fig. 5b) and are broadly correlated with those of Georgiev (2012).

With respect to the contractional deformation, pre-tectonic strata include all units beneath the sub-Tertiary unconformity. The overlying Palaeocene to lower Eocene succession may also be pre-kinematic, as resolved on the seismic data. Although stratigraphic thickness variations are evident in this sequence, these may reflect growth during immediately pre-contraction extensional faulting. In contrast, the next youngest sequence (Eoc-2 on Fig. 5) shows clear thickness variations together with differential onlap onto thrust-related folds. The overlying youngest Eocene strata (Eoc-3 on Fig. 5) do not show significant variation in thickness across the folds. Thus these strata seal the folds and contractional deformation.

The seismic relationships interpreted on Fig. 5 are equivalent to those presented by Sinclair et al. (1997). They describe a so-called Illyrian unconformity of Eocene age that dates the main Balkanide thrusting episode onshore. However, Oligocene strata in the Kamchia basin depicted on Fig. 5 show thickness variations and differential onlap across the folded top-Eocene surface. These relationships imply that deformation in the Kamchia Basin continued longer than is generally considered in the Balkanides onshore. Miocene and younger strata in contrast simply bury the thrust structures and fill the Kamchia basin. Upper Miocene and Pliocene strata step over onto the adjacent Moesian platform.

In summary, the seismic data used here develop an interpretation (Fig. 5) that is broadly in accord with that of Georgiev (2012, Fig. 3). The following megasequence designation is proposed. Notwithstanding interpretational uncertainty in the stratal relationships in the PalaeoceneEocene (Pal-Eoc-1 in Fig. 5), the sub-Tertiary unconformity plausibly forms the top of a pre-orogenic megasequence. The Miocene and Pliocene strata are postkinematic. However, the intervening Eocene and Oligocene strata do not form a simple syn-kinematic megasequence. Deformation, within the coverage of the seismic data, appears to have been pulsed. Two episodes of contraction (mid-Eocene and Oligocene contraction) are separated by a period of quiescence (late Eocene).

\section{Pre-orogenic megasequence boundary}

Mapping of the 3D seismic volume reveals the geometry of the sub-Tertiary unconformity at the base of syn and post orogenic megasequences adjacent to the Balkanide thrust system in the Kamchia Basin. This is defined by a continuous reflector that can be mapped as a surface through the data volume. On the Moesian platform this reflector oversteps reflectors to which it is discordant-relationships that imply the surface is an erosional unconformity. Miocene strata lie directly upon Cretaceous strata. This seismic surface maps into the flank of the Kamchia basin, retaining its discordant relationship with underlying reflectors erosional character. It passes down dip into a conformable surface and continues into the thrust belt. It therefore represents an ideal megasequence boundary consisting in part of an unconformity and in part by its conformable correlative surface.

The megasequence boundary has been mapped through the 3D seismic volume (Fig. 6a). On the Moesian platform it shows low relief and lies at a modern depth of about $1 \mathrm{~km}(\mathrm{c}$ $500 \mathrm{~ms}$ TWT). It can be traced down to depths of $8+\mathrm{km}$ (5000 ms TWT) in the SE corner of our study area-as it trends down into the Black Sea. Likewise the megasequence boundary can be traced beneath the Kamchia Basin towards the SW. Within this overall form, the boundary shows striking rugosity that is most pronounced in the shallower regions, along the margin of the Moesian platform. Figure $6 \mathrm{~b}$ illustrates, through serial sections, the form of such features. It has a depth approaching $1000 \mathrm{~ms}$ (TWT), equivalent to more than $1500 \mathrm{~m}$, and is just $4 \mathrm{~km}$ wide. We interpret these as erosional canyons and gullies, carved into strata of the Moesian platform. However, they can be traced to at least $2000 \mathrm{~ms}$ TWT, into Cretaceous strata of the Kamchia basin. Thus although the very uppermost part of these canyons may have been carved subaerially, certainly for the most part these must have submarine origins. It is likely that they are entirely submarine.

Within the seismic data used here we could not identify any fans of appropriate age that might have been sourced from the canyons. Any sediment flushed off the platform, together with the erosion products from the canyons themselves, are presumed to have been routed down the canyons, across the Kamchia Basin and into deeper areas in the western Black Sea. Significant thicknesses of Palaeocene strata are interpreted from deep seismic reflection profiles through the Black Sea (Nikishin et al. 2015). The absence of appropriate well penetrations in the basin make the location of these deposits conjectural.

The megasequence boundary steps over the fault that represents the tectonic margin of the Moesian platform. The geometry of this fault-unconformity system appears to 


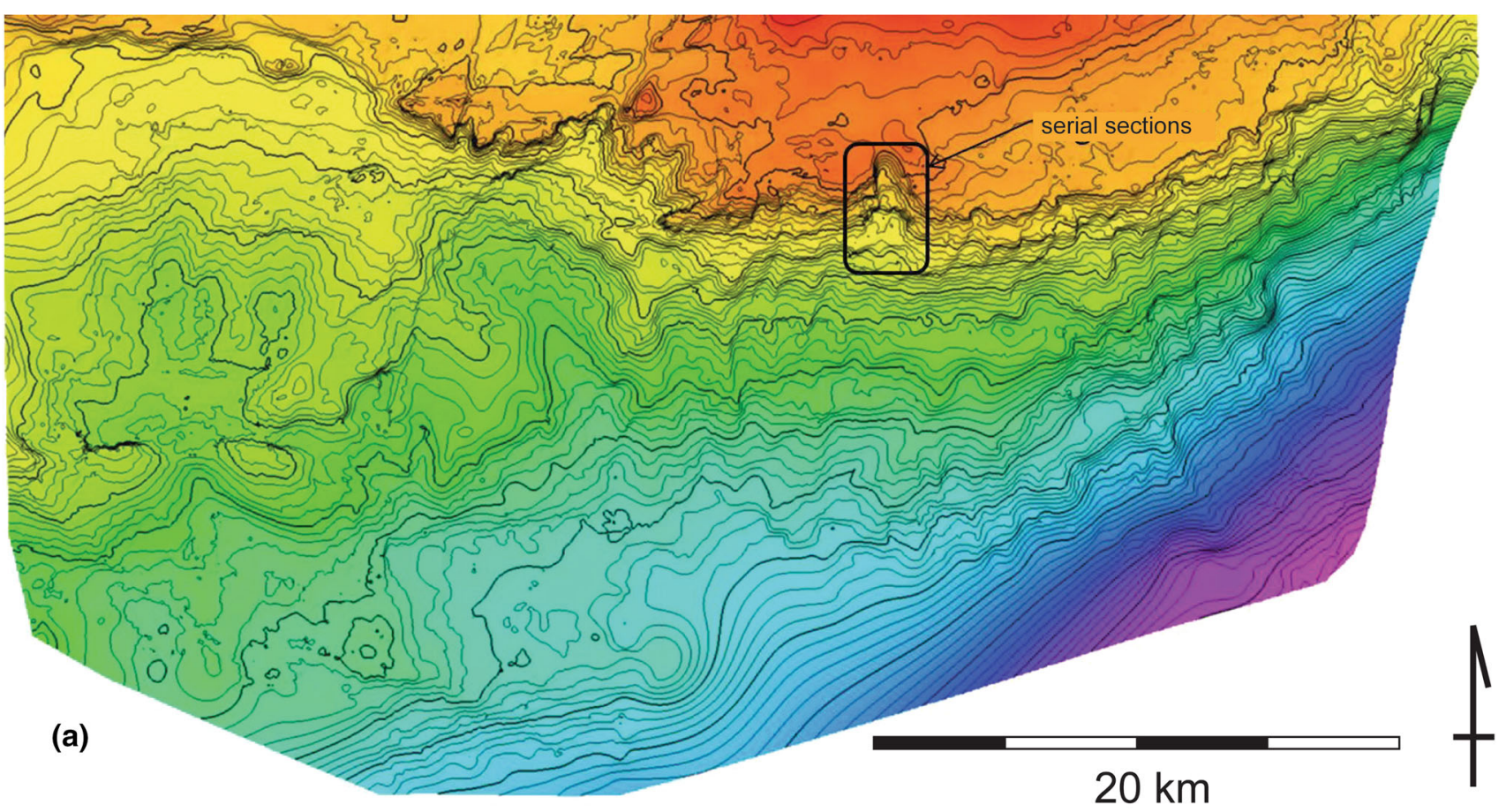

(b)
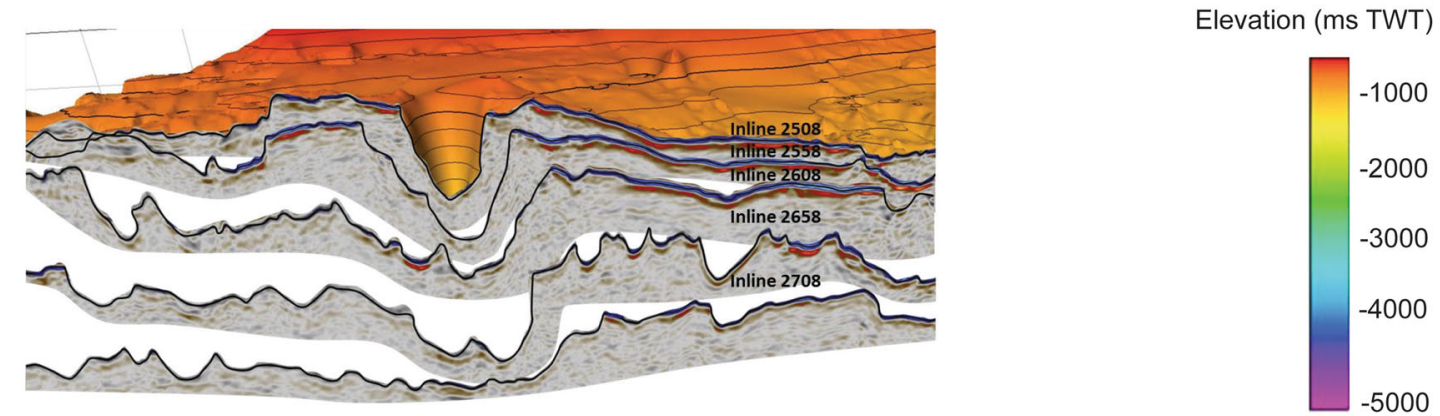

Fig. 6 a interpreted depth map (in TWT) of the sub-Tertiary unconformity through the 3D seismic volume. b detail of one canyon system (boxed area in a) showing serial cross-lines

form an abrupt margin to the Kamchia basin according to Georgiev (2012). However, this picture is misleading. As Stewart (2011) points out, vertical exaggeration can seriously obscure and mislead interpreters of seismic data. Consequently we show the tectonostratigraphic relationships on the northern margin of the Kamchia basin on a display with a vertical scale that approximates that of the horizontal (Fig. 5c).

\section{Tectono-stratigraphic evolution}

Although the deep structure of the Kamchia Basin and the frontal Balkan thrust system is not imaged in our seismic data (e.g. Fig. 5), we can use the stratigraphic relationships to develop tectonic understanding (Fig. 8). The basin has its origins in the rifting history that formed the Black Sea (e.g. Georgiev 2012; Nikishin et al. 2015). The margin of the weakly rifted Moesian platform is not defined by a single fault but rather an array of extensional structures that constitute the Bliznac fault zone. Much of the displacement on this structure predates the Cretaceous strata that drape it together with the unconformity that forms the base of the syn-orogenic megasequence. Although the basin acted as a foredeep to the developing Balkan orogeny, it had substantial bathymetry inherited from the pre-orogenic rifting phases. Consequently, contractional deformation along the Balkan thrust front began, and indeed terminated, under water.

Georgiev (2012) suggests that normal faults within the Kamchia Basin have reactivated under contraction to form the thrusts within the frontal Balkan system. We follow this interpretation (Fig. 8b). Only one such inverted normal fault can be interpreted in Fig. 5, identified on the basis of thickness variations especially in Cretaceous strata. However the use of strongly vertically exaggerated sections by 
Fig. 7 Schematic representation of the canyon system mapped in Fig. 6 and its inferred depositional systems that lies outside the study area

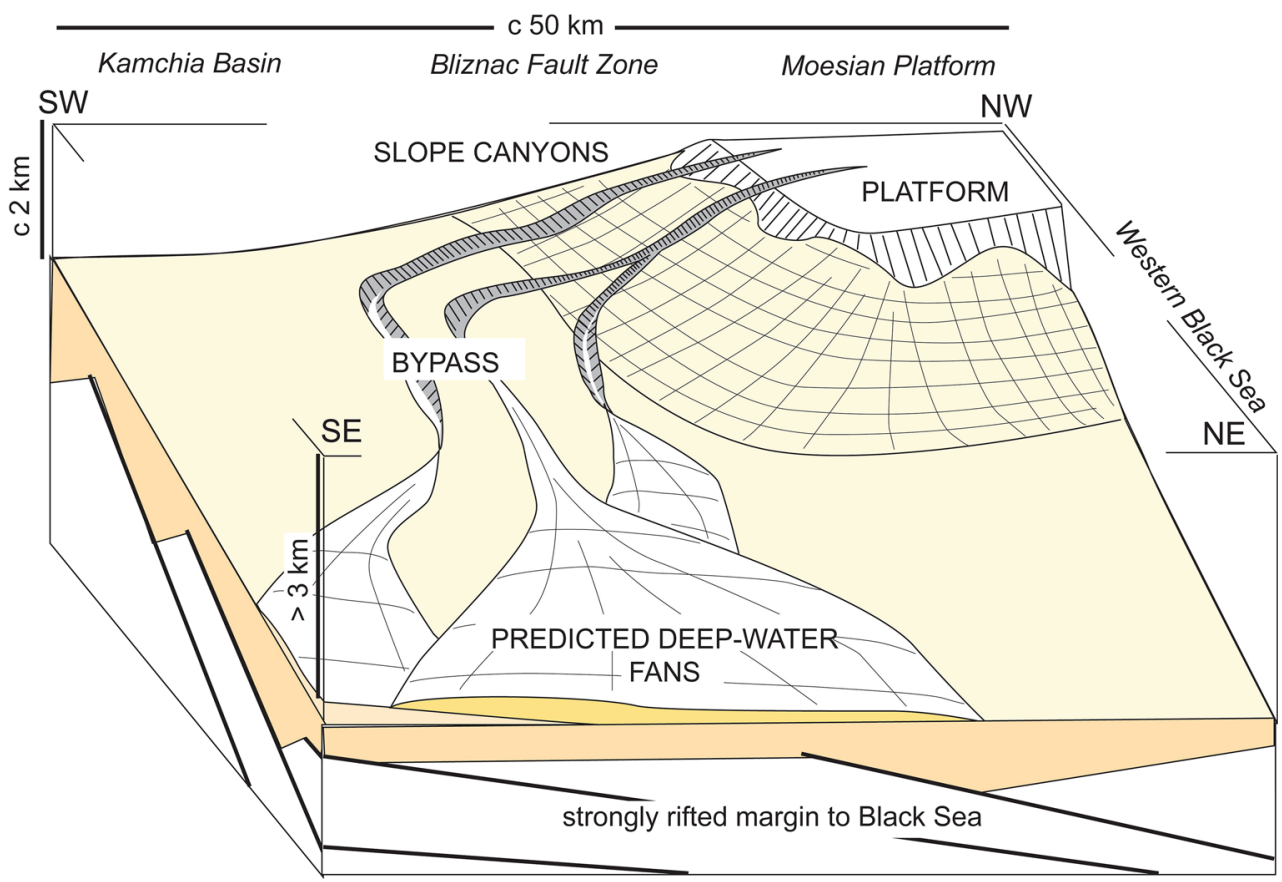

Georgiev (2012) may overemphasize the role of inversion tectonics within the thrust belt itself. Consequently we illustrate our interpretation (Fig. 5c) in near equalized vertical and horizontal scales. Clearly if simple fault reactivation, as illustrated in Fig. 8b, has happened the system remained broadly in net extension as the Kamchia basin remained significantly submerged.

For the main segment of the Balkanides onshore, Stuart et al. (2011) considered the Moesian Platform to have acted like a buttress to inversion of the former Kamchia basin. However, this is not the case. Regardless of the structural style within the Kamchia basin itself, there is no evidence for contractional deformation having been localized onto the basin-bounding Bliznac fault system. In this regard, our selected line (Fig. 5) typifies the basin margin as a whole. Even as deformation continued, as charted by the polyphase contractional activity along the Balkan thrust front, thrusting remained within the basin and not on its flanks.

\section{Discussion}

A rationale for our study is that the relationships between the Kamchia basin, the Balkan thrust belt and the Moesian platform provide analogues for various aspects for the tectonic development within more strongly deformed parts of the Alpine system together with stratigraphic relationships obscured by this deformation. We now draw these comparisons, addressing a series of themes.

\subsection{An analogue for former platform margins}

Erosion along the flank of the Kamchia Basin, as evidenced by the incised nature of the major unconformity surface that separates the Tertiary from Cretaceous strata on the Moesian platform (Fig. 7) implies significant sediment flux across the fledgling Kamchia Basin, presumably sourced from the Mesozoic carbonates of the Moesian platform. We infer that such deposits of reworked carbonates would inter-finger with the main siliciclastic fill of the Kamchia Basin that was derived axially from the adjacent Balkan orogeny onshore. There may be parallels elsewhere in the Tethyan system, including the Albidona Formation of the southern Apennines (Cesarano et al. 2002). This unit was deposited in the ancestral foredeep to the fledgling Apennine thrust system. While its main siliciclastic components were derived either from long-range continental sources, or the developing orogeny, it contains important carbonate turbidites. These are inferred to have been sourced from the Apulian platform (Fig. 2a) that, at the time formed part of the orogenic foreland. In this sense the Apulian and Moesian platforms would be directly comparable. In the Apennine case the margins of the foreland platform that faced the advancing orogeny are now hidden beneath thrust sheets. Thus the unconformity surface mapped here that links the Moesian platform to its adjacent basin may provide an analogue for the sediment routing systems. Its carbonate components are believed to have been sourced in part from the Apulian foreland platform, mixing with axially-delivered far-travelled siliciclastic turbidites. The 
margin of the Apulian platform is no longer preserved, having been caught up in Apennine thrusting. Therefore, the Moesian platform-Kamchia basin example described here may be an analogue for the sediment delivery routes by which carbonates were shed into the evolving Apennine foredeep.

\subsection{Buttressing, necking zones and margin inheritance}

Mohn et al. (2014) inferred that, for Alpine-type orogens, the major structural elements inherited from the heterogeneously stretched continental crust exerted a fundamental control on the loci of contractional tectonics (Fig. 1a, b). For these workers there is a major difference in structural style that occurs when deformation encounters the edge of the weakly rifted zone of a former rifted continental margin. This so-called "necking zone" (e.g. Mohn et al. 2012) marks a change from low-angle thrusting in the strongly rifted portion to a form of thicker-skinned tectonics. Our study of the Kamchia basin in the offshore gives an insight into such tectonic interpretations because orogenic evolution has been arrested before significant deformation obscured the initial structures.

According to regional interpretations (e.g. Nikishin et al. 2015), the southern and eastern margins of the Moesian platform represent the transition between near normal continental crust and significantly more stretched equivalents. In this context the platform edge overlies the necking zone. Within our study area, contractional deformation is restricted to the Kamchia basin that overlies the hyperextended continental crust, leaving the adjacent platform intact. There is no evidence of contractional deformation within the Bliznac fault system, along the edge of the Moesian platform. It is this structure that is the fault system that marks the necking zone. Of course if deformation had not stopped the Balkan orogen doubtless would have eventually encountered the Bliznac fault system and overthrust the edge of the Moesian platform as it has further to the west. However, our study area indicates that the necking zone is, in itself, not a locus for contraction.

Stratigraphic sections across basin margins are commonly displayed with significant vertical exaggeration that over-emphasize lateral changes in basin architecture (e.g. Stewart 2011). The geometry of the margin of the Moesian platform is rather less dramatic than that shown in the schematic restorations for the former European continental margin for the Alps by Mohn et al. $(2012,2014)$. The necking zone between the Moesian platform and the Kamchian basin, as charted by the sub-Tertiary unconformity (Figs. 5, 6), has an across-strike width of 10-15 km (Fig. 8). It therefore does not represent a steep buttress, in the sense originally defined in the western Alps (Barféty et al. 1979).

\subsection{Onset of deformation in strongly rifted regions}

The seismic data from the Kamchia Basin indicate that contractional deformation and the development of the Balkan thrust front happened underwater. Structural evolution can therefore be deduced from the imaged stratal relationships. These show, within the study area, a pulsed history with distinct periods of deformation in the mid Eocene and again in the Oligocene. For emergent thrust

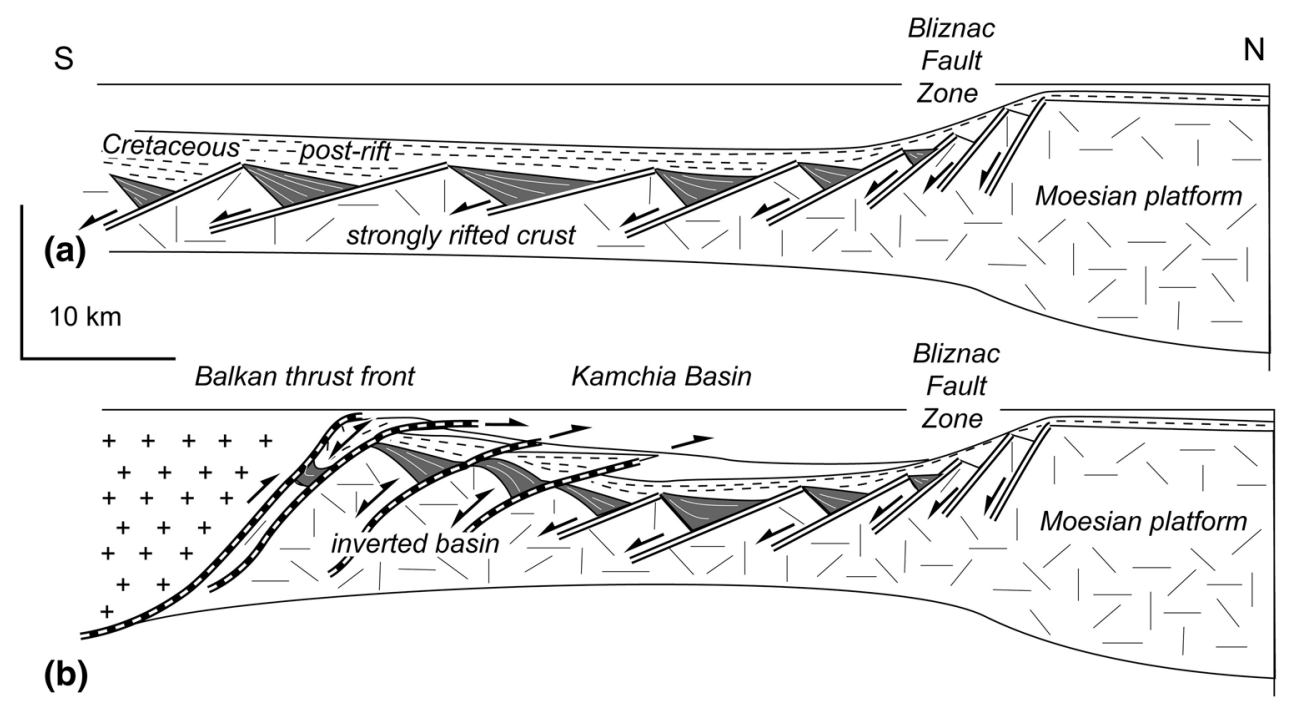

Fig. 8 Schematic representation of the structural evolution of the Kamchia basin and Moesian platform margin during Balkan orogenesis. a illustrates the geometry of the rifted continental margin that opened into the ancestral greater Black Sea basin (late Cretaceous). b illustrates the partial inversion of normal faults in the highly rifted margin. Note that there is no detectable reactivation of the platform margin (Bliznac fault zone) and that significant thrusting can occur in a submarine environment, ahead of the advancing orogeny 


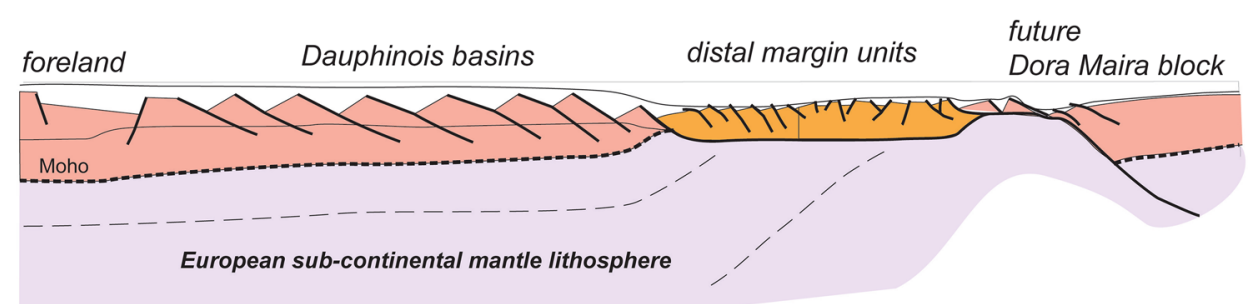

(a)

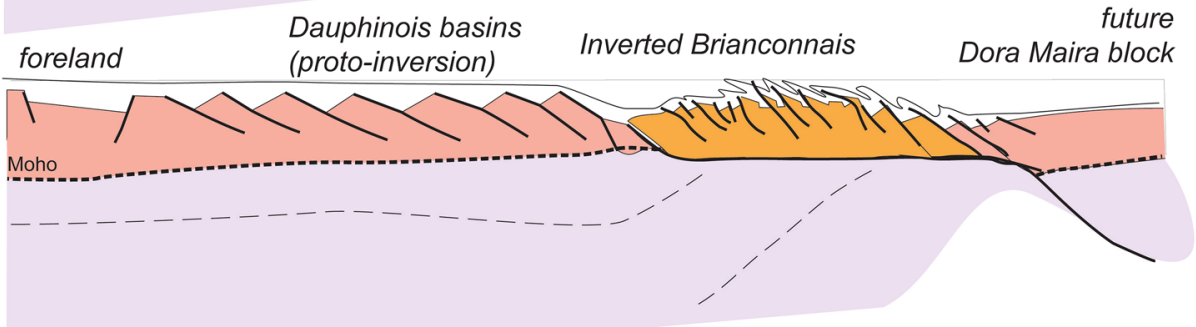

(b)

(c)

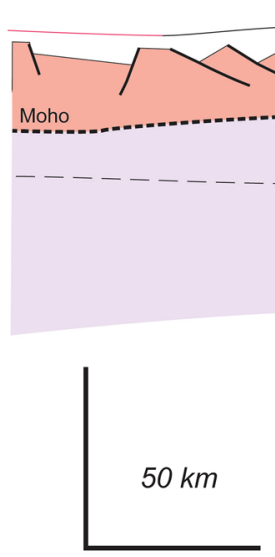

Fig. 9 Exploring the implications of structural evolution in the Kamchia basin for the development of western Alpine tectonics (compare with Fig. 1). a illustrates a pre-orogenic configuration of the former European continental margin before Alpine orogenesis after Butler (2013). b illustrates a speculative geometry of basin inversion

systems or areas with only poorly preserved syn-tectonic strata such pulsed histories would be difficult to recognize.

However, normal faults in the Kamchia basin have, at least locally, been reactivated. As the basin was strongly underfilled at the time, this inversion happened underwater. Given the water depth implied by the continuation of canyon incision in the sub-Tertiary unconformity, presumably of c $2+\mathrm{km}$, significant shortening could have been accumulated on these structures before they became subaerial.

Direct comparisons between the Kamchia basin and the western Alps are of course conjectural. However, it may be a good analogue for the Brianconnais and other portions of the strongly rifted former continental margin of Europe (Fig. 9). Existing models of the Brianconnais imply that significant contractional deformation only occurred once it in the Brianconnais and adjacent strongly rifted domains ahead of the main Alpine orogeny (not shown). $\mathbf{c}$ illustrates the incorporation of these inverted basin structures into the subduction channel where they acquire their distinctive metamorphic signatures (as described by Michard et al. 2004)

had become buried by advancing thrust sheets. For Michard et al. (2004; Fig. 1c, d), the various Brianconnais thrust sheets can be restored on the basis of their peak metamorphic pressures that chart different burial depths in the subduction channel. However, this interpretation does not preclude a period of contractional deformation within the Brianconnais that was emergent, ahead of the advancing thrust front (Fig. 9b). It would be this restructured, inverted Brianconnais and other parts of the rifted margin that would be reimbricated within the subduction channel (Fig. 9c). This, together with pre-existing complex rift geometries, may explain some of the complex structural relationships within the Brianconnais that are not readily explained by a single episode of thrust tectonics.

A challenge for Brianconnais studies is to recognize deformation that happened after the development of the 
Jurassic rift systems and before syn to post-metamorphic displacements. Unlike the Kamchia basin, there is no thick syn-kinematic succession. The youngest strata preserved are the "Flysch Noir", of Eocene age, that is traditionally used to provide an old age bracket on Alpine deformation (e.g. Dumont et al. 2012). This unit is generally strongly deformed but would hold the key to reconstructing preburial deformation. Indications that the Brianconnais system was deformed prior to at least some Flysch Noir deposition is indicated by local angular unconformities beneath it (e.g. Gidon et al. 1994).

\section{Conclusion}

The Kamchia basin and margin of the adjacent Moesian platform can form an analogue for the transition between weakly and strongly rifted continental crust that, in many orogenic systems, have become strongly deformed and hard to interpret. The basin now contains the Balkan thrust front that shows a pulsed development. Thrusting happened in a submarine setting with deformation tracked in seismic depositional sequences. While normal faults within the basin may have reactivated under contraction to localize thrusts, the former "necking zone" for continental rifting, represented by the Bliznac fault system, as not reactivated or controlled contractional deformation. These relationships may have parallels in the Western Alps. The analogous distal European margin strata in the Alps may have experienced significant contractional deformation before entering the subduction channel and being sliced and transported as thrust sheets. It remains unclear whether the transition between strongly rifted and weakly rifted continental crust served to localize deformation in the Alps. Indications from the Kamchia-Moesian margin suggest that it need have not.

Mapping the pre-Tertiary unconformity through the Kamchia basin reveals significant erosional canyons that testify to a sediment routing system from the Moesian platform into the fledgling foredeep basin to the Balkan orogen. It may provide an analogue for the mixed turbidite systems of the ancestral Apennine foredeep where Apulian (platform) derived carbonate turbidites interfinger with siliciclastics.

Acknowledgements CB acknowledges financial support from Optimus (Aberdeen) ltd. Petroceltic International plc are thanked for providing access to the subsurface data used in this study and for permission to publish images used here. Schlumberger are thanked for providing use of Petrel software under their academic agreement with the University of Aberdeen. RWHB thanks the organisers of the 12th Emile Argand Conference on Alpine Geological Studies for the invitation and financial support to participate in the Montgenevre workshop. Reviewers Enrico Tavarnelli, Thierry Dumont and editors Christian Sue and Stefan Schmid are all thanked for their comments that have significantly improved this contribution.
Open Access This article is distributed under the terms of the Creative Commons Attribution 4.0 International License (http://crea tivecommons.org/licenses/by/4.0/), which permits unrestricted use, distribution, and reproduction in any medium, provided you give appropriate credit to the original author(s) and the source, provide a link to the Creative Commons license, and indicate if changes were made.

\section{References}

Argand, E. (1916). Sur l'arc des Alpes Occidentales. Eclogae Geologicae Helvetiae, 14, 145-191.

Barféty, J. C., Gidon, M., Lemoine, M., \& Mouterde, R. (1979). Tectonique synsédimentaire liasique dans les massifs cristallins de la zone externe des Alpes occidentales francaises: la faille du col d'Ornon. Comptes rendus de l'académie des sciences, Paris, 289, 1207-1210.

Bellahsen, N., Jolivet, L., Lacombe, O., Bellanger, M., Boutoux, A., Garcia, S., et al. (2012). Mechanisms of margin inversion in the external Western Alps: Implications for crustal rheology. Tectonophysics, 560-561, 62-83.

Butler, R. W. H. (1989). The influence of pre-existing basin structure on thrust system evolution in the western Alps. In M. A. Cooper \& G. D. Williams (Eds.), Inversion tectonics (Vol. 44, pp. 105-122). London: Special publications of the Geological Society.

Butler, R. W. H. (2013). Area balancing as a test of models for the deep structure of mountain belts, with specific reference to the Alps. Journal of Structural Geology, 52, 2-16.

Butler, R. W. H., Tarvarnelli, E., \& Grasso, M. (2006). Structural inheritance in mountain belts: An Alpine-Apennine perspective. Journal of Structural Geology, 28, 1893-1908.

Cesarano, M., Pierantoni, P. P., \& Turco, E. (2002). Structural analysis of the Albidona Formation in the Alessandria del Carretto-Plataci area (Calabro-Lucanian Apennines, Southern Italy). Bollettino della Società geologica italiana, 1, 669-676.

Collet, L. W. (1927). The structure of the Alps. London: Edward Arnold \& Co.

Dumont, T., Champagnac, J. D., Crouzet, C., \& Rochat, P. (2008). Multistage shortening in the Dauphiné zone (French Alps): the record of Alpine collision and implications for pre-Alpine restoration. Swiss Journal of Geosciences, 101, S89-S110.

Dumont, T., Schwartz, S., Guillot, S., Simon-Labric, T., Tricart, P., \& Jourdan, S. (2012). Structural and sedimentary records of the Oligocene revolution in the Western Alpine Arc. Journal of Geodynamics, 56-57, 18-38.

Georgiev, G. (2012). Geology and hydrocarbon systems in the Western Black Sea. Turkish Journal of Earth Sciences, 21, 723-754.

Gidon, M., Kerckhove, C., Michard, A., Tricart, P., \& Goffé, B. (1994). Aiguille de Chambeyron. Notice explicative de la Carte géologique détaillée de la France à $1 / 50.000^{\circ}$, feuille. Orléans: B.R.G.M.

Jackson, J. A. (1980). Reactivation of basement faults and crustal shortening in orogenic belts. Nature, 283, 343-346.

Michard, A., Avigad, D., Goffé, B., \& Chopin, C. (2004). The highpressure metamorphic front of the sout Western Alps (UbayeMaira transect, France, Italy). Schweizerische Mineralogische und Petrographische Mitteilungen, 84, 215-235.

Mohn, G., Manatscahl, G., Beltrando, M., \& Haupert, I. (2014). The role of rift-inherited hyper-extension in Alpine-type orogens. Terra Nova, 26, 347-353.

Mohn, G., Mohn, G., Manatschal, G., Beltrando, M., Masini, E., Kusznir, N. (2012). Necking of continental crust in magma-poor 
rifted margins: evidence from the fossil Alpine Tethys margins. Tectonics, 31, TC1012.

Nikishin, A. M., Okay, A., Tüysüz, O., Demirer, A., Wannier, M., Amelin, N., et al. (2015). The Black Sea basins structure and history: New model based on new deep penetration regional seismic data. Part 2: Tectonic history and paleogeography. Marine and Petroleum Geology, 59, 656-670.

Sinclair, H. D., Juranov, S. G., Georgiev, G., Byrne, P., Mountney, N. P. (1997). The Balkan thrust wedge and foreland basin of Eastern Bulgaria: Structural and stratigraphic development. In: A.G. Robinson (Ed.), Regional and petroleum geology of the Black Sea and surrounding region. (Vol. 68, pp. 91-114). Tulsa, Oklahoma: American Association of Petroleum Geologists Memoir.
Stampfli, G. M., \& Hochard, C. (2009). Plate tectonics of the Alpine realm. In J. B. Murphy, J. D. Keppie, \& A. J. Hynes (Eds.), Ancient orogens and modern analogues (Vol. 327, pp. 89-111). London: Special publications of the Geological Society.

Stewart, S. A. (2011). Vertical exaggeration of reflection seismic data in geoscience publications 2006-2010. Marine and Petroleum Geology, 28, 959-965.

Stuart, C. J., Nemcok, Vangelov, D., Higgins, E. R., Welker, C., \& Meaux, D. P. (2011). Structural and depositional evolution of the East Balkan thrust belt, Bulgaria. Bulletin of the American Association of Petroleum Geologists, 95, 649-673.

Zhao, L., Paul, A., Guillot, S., Solarino, S., Malusà, M. G., Zheng, T., et al. (2015). First seismic evidence for continental subduction beneath the Western Alps. Geology, 43, 815-818. 